\title{
Global South Urbanisms and Urban Sustainability-Challenges and the Way Forward
}

\author{
Godwin Arku $^{1 *}$ and Lochner Marais ${ }^{2 *}$ \\ ${ }^{1}$ Department of Geography and Environment, The University of Western Ontario, London, ON, Canada, ${ }^{2}$ Centre for \\ Development Support, University of the Free State, Bloemfontein, South Africa
}

Keywords: ordinary cities, urbanization, sustainability, smart cities, urban diversity

\section{INTRODUCTION}

The "Cities of the Global South" section of Frontiers in Sustainable Cities is the first journal section to focus explicitly on urban issues in the Global South. The section's goal is to advance cuttingedge research in the field of Global South urbanization, urbanisms, and urban sustainability. In this inaugural editorial, we pick out three themes that distinguish this research agenda today: ordinary cities, managing urban areas, and urban sustainability. These themes highlight current trends in the urbanization of the Global South that have emerged as being of particular importance to urban sustainability, and are broad enough to engage a wide range of approaches and disciplines. The themes are not exhaustive or exclusive, but are intended rather to invite and challenge the global community of urban researchers and practitioners to respond and to expand the research agenda

\section{OPEN ACCESS}

Edited and reviewed by: Ruth Massey,

University of Huddersfield, United Kingdom

*Correspondence: Godwin Arku garku@uwo.ca Lochner Marais

MaraisJGL@ufs.ac.za

Specialty section:

This article was submitted to Cities in the Global South,

a section of the journal

Frontiers in Sustainable Cities

Received: 09 April 2021

Accepted: 31 May 2021

Published: 25 June 2021

Citation:

Arku G and Marais L (2021) Global

South Urbanisms and Urban

Sustainability - Challenges and the

Way Forward

Front. Sustain. Cities 3:692799.

doi: 10.3389/frsc.2021.692799 on Global South cities and urban sustainability.

\section{ORDINARY CITIES: DIVERSITY, CONTESTATION, AND DISTINCTIVENESS}

In the 1990s a focus on large or global cities dominated urban research. This helped diversify urban studies but over-emphasized economic flows and global networks. The work primarily emphasized urban hierarchies (Robinson, 2002). Although several cities in the Global South have started to emerge as global cities, this is not where most urban people live, and African cities are generally underrepresented. Research has emphasized a wide range of issues to do with globalization and paid less attention to the space of cities themselves. The focus on hierarchy in the global cities also creates the impression that the most important urban examples are those at the top of the hierarchy. However, many cities remain "off the map" because they have limited global connections and this global focus has consigned a large number of them around the world to "theoretical irrelevance" (Robinson, 2015, p. 71). We hope this new section on cities of the Global South will help us to understand these issues related to globalization. We hope to see the differences explained in terms of diversity rather than hierarchy. By focusing on diversity, contestations, and distinctiveness it will be possible to emphasize "a world of ordinary cities" in the Global South rather than looking exclusively at "world cities" (Robinson, 2015).

\section{MANAGING URBAN AREAS}

The second theme is the management of urbanization in the Global South. Current urbanization projections suggest that cities in the Global South, especially in East Asia, South Asia, and Africa, could be at the receiving end of $96 \%$ of an over three billion increase in urban population by 
2050 (The Lancet, 2017; Onodugo and Ezeadichie, 2020; UNHabitat, 2020). Three countries in particular, India, China, and Nigeria, could account for $35 \%$ of the total increase in global urban population from 2018 to 2050 (UN-Habitat, 2020).

The Global South now has some of the world's largest cities. By 2018, 28 megacities had emerged, providing a home for a total of 453 million people. Of these, 16 are in Asia, four in Latin America, and three in Africa (UNDESA, 2018). Dhaka, in Bangladesh, for instance, is one of the fastest-growing megacities globally, with an estimated population of over 17.6 million within its 1,528 square kilometer area, and is expected to have close on 26 million by 2,035 (Ahmed et al., 2018). In the rapidly urbanizing regions of Asia, economic growth has not always been coupled with efforts to include sustainability more explicitly in urban development agendas (Ooi, 2009).

The megacities of the Global South have major socioeconomic and environmental problems, such as in increase in slum-dwellers, air and water pollution, resource depletion, and rising urban poverty. Delhi, Mumbai, and Dhaka, among others, are experiencing a serious shortage of land supply and a rapidly deteriorating urban environment. Megacities in Latin America, such as São Paulo and Rio de Janeiro, continue to grow without adequate planning and to experience increasing inequity (Hardoy et al., 2019). In Africa, urban growth is concentrated in unplanned informal settlements with an acute shortage of critical infrastructure and basic services (UNDP, 2017). About $60 \%$ of urban residents in Africa live such settlements, making them highly vulnerable to climate change (Taylor and Peter, 2014; Bandauko et al., 2021).

These dynamics raise several important questions: Can urbanization in the Global South be better planned and managed to speed up the eradication of poverty, reduce inequality, address climate change emergencies, enhance gender equality, and provide productive employment to drive economic growth? Is an inclusive city possible in the Global South? What are the social and political implications of urban marginalization in the Global South? As some scholars have argued, the new urban geography in many Global South cities has given rise to an antipoor politics often spearheaded by new and more established middle-class groups of residents (see Swanson, 2007; Baviskar and Ray, 2011). What are the implications of these new urban geographies for the "right to the city" in the Global South?

Most Global South countries, especially those in Africa, are facing the challenge of developing a more functionally integrated, spatially coherent, economically competitive, environmentally sustainable, and socially inclusive urban environment (Arku, 2009; Cobbinah and Darkwah, 2017). This puts considerable strain on urban leaders and policymakers and compromises their ability to manage change. Weak and fragmented governments in the Global South have limited capacity to engage with critical urban issues like inequality and poverty, slums, climate change, and environmental deterioration (Dodman et al., 2017). These problems are often the result of poorly planned rapid urbanization (The Lancet, 2017); which raises more questions: What must cities in the Global South do differently to achieve resilient and sustainable urban development as set out in Sustainable Development Goal 11 and the New
Urban Agenda? What new models and approaches can be adopted to plan and manage urbanization sustainably in the rapidly growing cities of the Global South? These urbanization projections and realities in the Global South make it imperative for city planners and managers to move away from the traditional planning systems and explore inclusive and innovative planning approaches that can address the current and emerging urban realities.

Secondary cities have emerged in the Global South as a strategy to manage urbanization (Marais and Cloete, 2017). However, the question is no longer how secondary cities can be used to contain urbanization. Rather, as argued by the (World Bank, 2010, p. viii), the question is "how to prepare for it and how to reap the benefits associated with the relationship between urbanization and economic growth in the process of managing the negative impacts." In addition, secondary cities in Asia, Africa, and Latin America are deploying several innovative urban governance approaches to drive adaptive futures in the face of critical urbanization pressures. Some of these approaches are transnational municipal corporations, community-driven adaptation programs, innovative self-governance models, and public-private partnerships (Adelina et al., 2020). This raises yet another question: What lessons can we draw from these experiences of planning urban transformation in the Global South?

\section{URBAN SUSTAINABILITY AND SUSTAINABILITIES}

The third theme is urban sustainability and ways to achieve it in the Global South. We raise some critical questions: How is sustainability framed and understood in the Global South? What urban sustainability narratives are currently dominant in Global South cities and what are their implications for policy and practice? We would also want to ask: Sustainability for whom? The framing of urban sustainability in the Global South is often modeled on urban experiences from the Global North, despite the fundamental differences in basic services and resources (Fernández, 2014). We recognize that, because of their problems of inequality, poverty, and infrastructure deficits, cities of the Global South may struggle with issues of sustainability, but researchers should consider how these conditions might give rise to "novel pathways to urban sustainability" (Fernández, 2014, p. 598). What novel pathways might these problems suggest?

The question of "sustainability for whom" is critical because many cities in the Global South use "slum clearance" as an urban development measure (Weinstein, 2014; Ahmed and Meener, 2018; UN-Habitat, 2020). Thus, it is essential for urban authorities and policymakers to adopt and apply the concept of just sustainability, to maintain a proper balance between urban development and the rights of slum-dwellers. This concept prioritizes justice and equality without disregarding the importance of the environment or the surrounding ecological systems (Ahmed and Meener, 2018). The question then becomes: how can we achieve just sustainability in the Global South, where urban poverty, inequality, and marginalization have become 
the common outcomes of the urbanization process? Despite the negative externalities associated with urbanization in the Global South, these cities have strong imperatives, and unique but often overlooked capacity to innovate and experiment (Nagendra et al., 2018). For example, the extensive urban growth and development anticipated in sub-Saharan Africa offers considerable opportunity to deal proactively with vulnerability and the risk of disaster. It is therefore important to focus on the opportunities and potential for resilience-building in emerging urban centers: conceptualizing urban physical environments merely as "sites of risk" misses seeing them as "wellsprings of environmental opportunities” (Myers, 2016, p. 90).

Faced with the challenge of precarious urbanization, policymakers in the Global South are experimenting with new modes of urban development to deal with the current "urban crisis." Some scholars have argued that the Global South is currently undergoing an "urban revolution." From the megaurbanization of Lusaka, to the production of satellite cities in Kenya, Ghana, and Jakarta, to new cities built from scratch in Masdar, Songdo, and Rajarhat, this process is now the persistent feature of "utopian visions" that seek to expedite the production of new cities (Datta and Shaban, 2016). More than 500 smart city projects are in progress (Atha et al., 2020). India and Indonesia have programs aiming to produce 100 smart cities. In both countries, national governments have used these multi-billion dollar projects as disruptive strategies to solve "old urban problems." The idea is to master-plan new urban enclosures or satellite cities, termed "eco cities," "smart cities," or "future cities." They are intended to be built from scratch and powered by green technologies that allow for efficient city management,

\section{REFERENCES}

Adelina, C., Archer, D., Johnson, O., and Opiyo, R. (2020). Governing Sustainability in Secondary Cities of the Global South. SEI Report. Stockholm: Stockholm Environment Institute

Ahmed, S., and Meener, M. (2018). Just sustainability in the Global South: a case study of the megacity of Dhaka. J. Dev. Soc. 34, 401-424. doi: 10.1177/0169796X18806740

Ahmed, S., Nahiduzzaman, K. M., and Hasan, M. M. U. (2018). Dhaka, Bangladesh: unpacking challenges and reflecting on unjust transitions. Cities 77, 142-157. doi: 10.1016/j.cities.2017.11.012

Ajibade, I. (2017). Can a future city enhance urban resilience and sustainability? A political ecology analysis of Eko Atlantic City, Nigeria. Int. J. Disast. Risk. Reduct. 26, 85-92. doi: 10.1016/j.ijdrr.2017.09.029

Arku, G. (2009). Rapidly growing African cities need to adopt smart growth policies to solve urban development concerns. Urban For. 20, 253-270. doi: $10.1007 / \mathrm{s} 12132-009-9047-\mathrm{z}$

Atha, K., Callahan, J., Chen, J., Drun, J., Green, K., Lafferty, B., et al. (2020). China’s Smart Cities Development. Research Report Prepared on Behalf of the U.S. China Economic and Security Review Commission. Available online at: https://www. uscc.gov/sites/default/files/2020-04/China_Smart_Cities_Development.pdf

Bandauko, E., Annan-Aggrey, E., and Arku, G. (2021). Planning and managing urbanisation in the twenty-first century: content analysis of selected African countries' national urban policies. Urban Res. Pract. 14, 94-104. doi: $10.1080 / 17535069.2020 .1803641$

Baviskar, A., and Ray, R. (eds.). (2011). Elite and Everyman: The Cultural Politics of the Indian Middle Classes. New York, NY: Routledge. cleaner air quality, and economic growth (Watson, 2014; Moser, 2015). The primary justification for these new cities is that they incorporate urban sustainability in their planning and design, making them different from "traditional" existing cities. These smart cities and their associated technologies could revolutionize the way Global South cities are planned, managed, and governed; however, questions can be raised. For example, do they live up to their promise of promoting urban sustainability in the Global South? Do they consider the socio-economic dimensions of urbanization? An analysis of Eko Atlantic City, Lagos, Nigeria, found that this new city became a zero-sum project that increased social inequality and created an unsustainable adaptation trajectory (Ajibade, 2017). This is mainly because it was planned as an urban elitist project, with no socio-economic inclusion. Thus, questions still linger: Is the construction of new cities the answer to urban sustainability problems in the Global South? What alternative pathways to urban sustainability can be applied in Global South cities?

As editors of this new "Cities of the Global South" section of Frontiers in Sustainable Cities, we invite cutting-edge papers that critically engage with the challenges of urbanization and provide innovative suggestions on how urbanization can be better planned and managed to reap its potential economic development benefits.

\section{AUTHOR CONTRIBUTIONS}

All authors listed have made a substantial, direct and intellectual contribution to the work, and approved it for publication.

Cobbinah, P. B., and Darkwah, R. M. (2017). Toward a more desirable form of sustainable urban development in Africa. Afr. Geogr. Rev. 36, 262-285. doi: 10.1080/19376812.2016.1208770

Datta, A., and Shaban, A. (eds.). (2016). Mega-Urbanization in the Global South: Fast Cities and New Urban Utopias of the Postcolonial State. London: Routledge. doi: 10.4324/9781315797830

Dodman, D., Leck, H., Rusca, M., and Colenbrander, S. (2017). African urbanisation and urbanism: implications for risk accumulation and reduction. Int. J. Disast. Risk Reduct. 26, 7-15. doi: 10.1016/j.ijdrr.2017.06.029

Fernández, J. E. (2014). “Urban metabolism of the Global South," in The Routledge Handbook on Cities of the Global South, eds S. Parnell and S. Oldfield (New York, NY: Routledge), 597-613.

Hardoy, J., Gencer, E., and Winograd, M. (2019). Participatory planning for climate resilient and inclusive urban development in Dosquebradas (Colombia), Santa Ana (El Salvador) and Santa Tomé (Argentina). Environ. Urban. 31, 33-52. doi: $10.1177 / 0956247819825539$

Marais, L., and Cloete, J. (2017). The role of secondary cities in managing urbanisation in South Africa. Dev. South Afr. 34, 182-195. doi: 10.1080/0376835X.2016.1259993

Moser, S. (2015). New cities: old wine in new bottles? Dialogues Hum. Geogr. 5, 31-35. doi: 10.1177/2043820614565867

Myers, G. (2016). Urban Environments in Africa: A Critical Analysis of Environmental Politics. Bristol: Policy Press. doi: 10.1332/policypress/9781447322917.001.0001

Nagendra, H., Bai, X., Brondizio, E. S., and Lwasa, S. (2018). The urban south and the predicament of global sustainability. Nat. Sust. 1, 341-349. doi: 10.1038/s41893-018-0101-5 
Onodugo, A. V., and Ezeadichie, H. N. (2020). "Future planning of Global South cities with inclusive informal economic growth in perspective," in Sustainability in Urban Planning and Design, eds A. Almusaed, A. Almssad, and L. TruongHong (London: IntechOpen). doi: 10.5772/intechopen.89145

Ooi, G. L. (2009). Challenges of sustainability for Asian urbanisation. Curr. Opin. Environ. Sustain. 1, 187-191. doi: 10.1016/j.cosust.2009.09.001

Robinson, J. (2002). Global and world cities: a view from off the map. Int. J. Urban Reg. 2, 531-554. doi: 10.1111/1468-2427.00397

Robinson, J. (2015). "World cities of a world of ordinary cities?", in Cities of the Global South Reader, eds F. Miraftsb and N. Kudva (London: Routledge), 66-72.

Swanson, K. (2007). Revanchist urbanism heads south: The regulation of indigenous beggars and street vendors in Ecuador. Antipode 39, 708-728. doi: $10.1111 / \mathrm{j} .1467-8330.2007 .00548 . \mathrm{x}$

Taylor, A., and Peter, C. (2014). Strengthening Climate Resilience in African Cities. A Framework of Working with Informality. Cape Town: Africa Center for Cities.

The Lancet (2017). Editorial: urbanisation, inequality, and health in Asia and the Pacific. Lancet 389, 1-8. doi: 10.1016/S0140-6736(17)30941-8

UNDESA (2018). 2018 Revision of World Urbanization Prospects. United Nations Department for Economic and Social Affairs. Available online at: https://esa.un. org/unpd/wup/

UNDP (2017). Leveraging Urbanization and Governance for Growth in Africa: A Framework for Action. Addis Ababa: UNDP.
UN-Habitat (2020). World Cities Report 2020: The Value of Sustainable Urbanization. Nairobi: United Nations Human Settlements Programme (UNHabitat).

Watson, V. (2014). African urban fantasies: dreams or nightmares? Environ. Urban. 26, 215-231. doi: 10.1177/095624781351 3705

Weinstein, L. (2014). The Durable Slum: Dharavi and the Right to Stay Put in Globalizing Mumbai. Minneapolis, MN: University of Minnesota Press.

World Bank (2010). Systems of Cities. Harnessing Growth for Urbanization and Poverty Alleviation. Finance, Economic and Urban Department, World Bank. Washington, DC: World Bank.

Conflict of Interest: The authors declare that the research was conducted in the absence of any commercial or financial relationships that could be construed as a potential conflict of interest.

Copyright (c) 2021 Arku and Marais. This is an open-access article distributed under the terms of the Creative Commons Attribution License (CC BY). The use, distribution or reproduction in other forums is permitted, provided the original author(s) and the copyright owner(s) are credited and that the original publication in this journal is cited, in accordance with accepted academic practice. No use, distribution or reproduction is permitted which does not comply with these terms. 